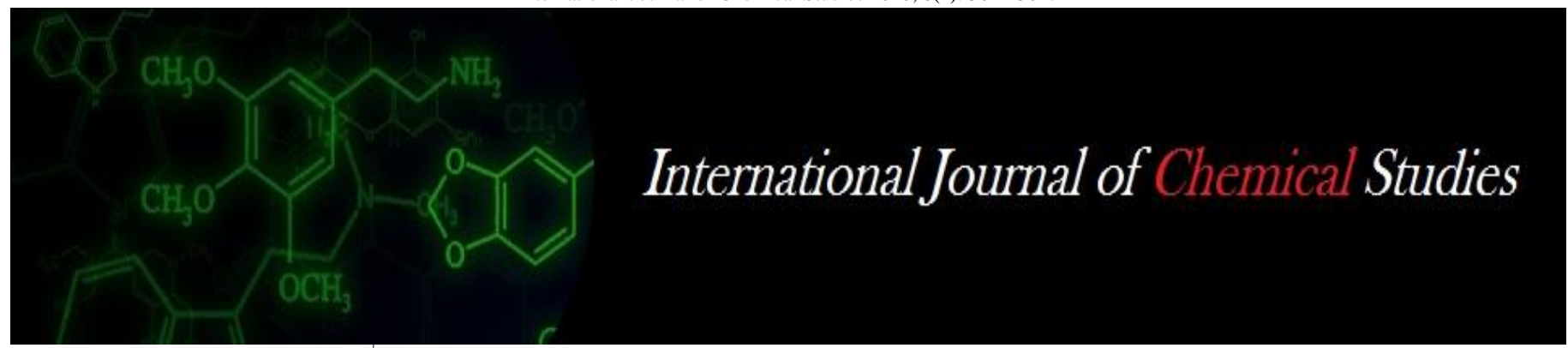

P-ISSN: 2349-8528

E-ISSN: 2321-4902

www.chemijournal.com

IJCS 2020; 8(4): 3644-3647

(C) 2020 IJCS

Received: 14-05-2020

Accepted: 27-06-2020

Pandidurai G

Research Scholar, Department of Food Science and Nutrition, Community Science College and Research Institute, Tamil Nadu Agricultural University,

Madurai, Tamil Nadu, India

\section{Vennila $\mathbf{P}$}

Department of Post Harvest

Technology Centre, Agricultural

Engineering College and

Research Institute, Tamil Nadu

Agricultural University,

Coimbatore, Tamil Nadu, India

\section{Processing, value addition and effect of nutritional quality of fig fruit by osmatic dehydration}

\section{Pandidurai $\mathbf{G}$ and Vennila $\mathbf{P}$}

\author{
DOI: https://doi.org/10.22271/chemi.2020.v8.i4at.10213
}

\begin{abstract}
Fig fruits are storehouse of essential nutrients and phytochemicals which are rich in antioxidants and it is much valued in both the fresh and processed forms. Fig fruit is highly perishable due to their high water activity. It is essential to process the fig fruits to add value to it and also to increase their usage in our daily diet. Osmotic dehydration of fig fruit was carried out by using sugar as an osmotic agent at different concentration and the process was standardized and physico-chemical parameters and organoleptic characteristics of osmotically dehydrated fruits and control sample were studied. Results showed that the sample steeped in $50^{\circ}$ Brix was found to good quality and highly acceptable by the consumers. The chemical content of osmotically dehydrated fig fruits were moisture -9.47 per cent, TSS $-80.4^{\circ}$ Brix, acidity - 0.11 percent, $\mathrm{pH}-5.40$, total sugar $-76.04 \mathrm{~g} / 100 \mathrm{~g}$, reducing sugar $-4.29 \mathrm{~g} / 100 \mathrm{~g}$, fibre $5.94 \mathrm{~g} / 100 \mathrm{~g}$, ash - $5.94 \mathrm{~g} / 100 \mathrm{~g}$, vitamin C - $10.97 \mathrm{mg} / 100 \mathrm{~g}$, antioxidant - $109.34 \mathrm{mg} / \mathrm{g}$, water activity 0.744 and colour Lab values were $75.41,-1.50$ and 15.04 respectively. From the osmotically dehydrated fig fruits, the products laddu, fudge, cake, and cookies were prepared and organoleptic characteristics were studied. The incorporation levels of dehydrated fig fruits in the products were 5, 10, 15, 20 and 25 per cent respectively. Among the different level of incorporation 15 per cent scored higher consumer acceptability with respect to colour and appearance, flavor, texture, taste with optimum amount of nutritional content.
\end{abstract}

Keywords: Fig fruit, osmotic dehydration, organoleptic evaluation and brix

\section{Introduction}

Fig (Fiscus carica L.) is cultivated since ancient times and its remains found in at least 5000 B.C. In India, its cultivation is mostly confined to western part of Maharashtra, Gujarat, Uttar Pradesh, Karnataka, Punjab and Tamil Nadu. Fig is a delicious, nutritive fruit and has many medicinal properties. The health benefits of figs include promoting bowel function due to the high level of fibre. Figs are amongst the most alkaline foods, making them useful in balancing the $\mathrm{pH}$ of the body. It is a source of calcium which has many functions including promoting bone density and also contains several medical components such as flavones which can be used in cardiovascular disease medicine production. Additionally, Figs have good amount of vitamin $\mathrm{A}, \mathrm{C}$ and $\mathrm{E}$ which are considered an antioxidants can effectively prevent deficiencies and vision destroying diseases like macular degeneration (Wang et al., 2017; Bansode et al., 2012) ${ }^{[11,2]}$. Fig is consumed fresh, dried, preserved, freezed, canned and candied fruit. Being highly perishable fruit, the dried fruits can be stored for 6-8 months whereas fresh fruit is stored in refrigerator only for 2-3 days. The natural colour, flavor and texture of fruits are lost during mechanical dehydration process. Therefor to achieve good quality of dehydrated fruit a technique viz., osmotic dehydration is useful in combination with other drying methods. The product obtained by osmotic dehydration is more stable during storage due to low water activity impaired by solute gain and water loss. Shrinkage of the final product is avoided by osmotic dehydration techniques. Because of this, the present investigation was carried to study the fixing an optimum concentration of osmotic agent for osmotic dehydration of fig fruit.

\section{Material and Methods}

The study was conducted at Community Science College and Research Institute, Tamil Nadu Agricultural University, Madurai. 
The firm and ripened fig fruits (local variety) were purchased from local market and washed in running tap water than the fruits were steam blanched for 3-5 min for softening and also pre-sterilization to inactivate any insects present in them. After cooling the fruits were soaked in $30\left(\mathrm{~T}_{1}\right), 40\left(\mathrm{~T}_{2}\right)$, and $50{ }^{\circ}$ brix $\left(\mathrm{T}_{3}\right)$ sugar syrup containing $0.5 \%$ KMS solution $(1: 2$ fruit: sugar syrup ratio) for a period of $24 \mathrm{hrs}$. After the soaking period, the sugar syrup was drained out and the soaked fruits were pressed by using pressing machine. The pressed fruits in each treatment were dried at a temperature of $60{ }^{\circ} \mathrm{C}$ in a cabinet drier till it becomes dried (constant values obtained). A control ( $\left.\mathrm{T}_{0}\right)$ sample was also kept for comparison.

Organoleptic qualities (ASTM, 1968) ${ }^{[1]}$ were analysed for all the treatments for the selection of best treatment. The selected osmotically dehydrated fig fruit was analysed for nutritional characteristics (Ranganna, 1995) [9] and the products laddu (fig 1), fudge (fig 2), cookies (fig 3) and cake (fig 4) were prepared by adding dehydrated fig fruits in level of 5, 10, 15, 20 and 25 per cent. The prepared products were organoleptically evaluated and the best level of incorporation was selected for each product.

\section{Results and Discussion}

\section{Organoleptic evaluation}

The organoleptic evaluation of osmotic dehydrated fig fruit at different concentrations it was found that the overall acceptability of 8.29 soaked with $50^{\circ}$ brix followed by $40^{\circ}$ brix (7.36) and $30^{\circ}$ brix (6.69). The lowest acceptability of 5.75 was in control (Table 1). Similar results were obtained by Chavan et al. (2010) ${ }^{[3]}$ and Chenlo et al. (2006) ${ }^{[4]}$.

\section{Nutrient content}

The significant results were found between fresh and dehydrated fig fruit nutrient content (Table 2). The moisture content of fresh and osmotically dehydrated fig fruit was 79.80 and 9.47 percent respectively. This is due to the hypertonic sugar solution which replaces the moisture content and increases the shelf life. The TSS content of the fresh and dehydrated fig was 19 and 80.4 brix respectively. The acidity content was decreased to $0.11 \%$ from $0.19 \%$ after dehydration. The $\mathrm{pH}$ content of figwas increased from 5.10 to 5.40 after osmotic dehydration. The total sugar content of fresh and dehydrated fig was 18.04 and $76.04 \mathrm{~g} / 100 \mathrm{~g}$ respectively. The reducing sugar content of dehydrated fig fruit was $4.29 \mathrm{~g} / 100 \mathrm{~g}$ which was decreased from $8.35 \mathrm{~g} / 100 \mathrm{~g}$ after dehydration. The ash content and fibre was found to be increased from $1.57 \mathrm{~g}$ to $1.93 \mathrm{~g}$ and $2.05 \mathrm{~g}$ to $5.94 \mathrm{~g}$ respectively due to removal of water during osmotic dehydration. The vitamin $\mathrm{C}$ content of the dehydrated fig fruit was decreased from $39.0 \mathrm{mg} / 100 \mathrm{~g}$ to $10.97 \mathrm{mg} / 100 \mathrm{~g}$ after osmotic dehydration. The antioxidant value of dehydrated fig was $109.34 \mathrm{mg}$. The water activity was found to be 0.744 aw in dehydrated fig fruit. The colour lab values were $74.41,-1.50$ and 15.04 for dehydrated fig fruit. The similar results were in line with earlier finds of Dhingra et al. (2008) ${ }^{[5]}$; Hooti et al. (2008) ${ }^{[6]}$ and Paakkomen and Mattila (1991) ${ }^{[8]}$.

\section{Product development}

The selected osmotically dehydrated fig fruit (ODF) $\left(50^{\circ}\right.$ brix) was used to prepare products such as laddu, fudge, cookies, cake and boli. All products were prepared by adding osmotically dehydrated fig fruits (ODF) in powder form (5, $10,15,20$ and 25 per cent). The prepared products were organoleptically evaluated and based on the sensory evaluation it as found that for laddu prepared with adding 15 per cent ODF, fudge with 25 per cent ODF, cookies with 10 ODF, cake with 15 per cent ODF and boli with 20 per cent ODF was accounted highest organoleptic values (Fig. 6). The similar studies were also reported by Lerici et al. (1985) ${ }^{[7]}$ and Sharma et al. (2006) ${ }^{[10]}$.

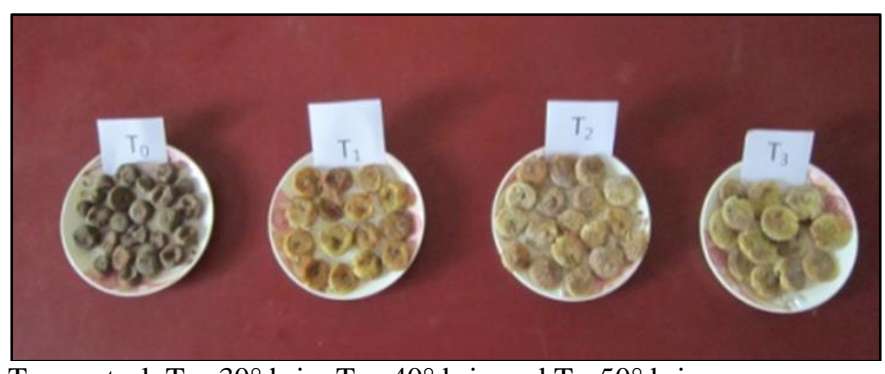

$\mathrm{T}_{\mathrm{o}}$ - control, $\mathrm{T}_{1}-30^{\circ}$ brix, $\mathrm{T}_{2}-40^{\circ}$ brix and $\mathrm{T}_{3}-50^{\circ}$ brix

Fig 1: Osmotically dehydrated fig fruit (ODF)

Selection of good quality ingredients

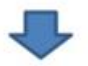

Adding the ingredients in correct proportion (ODF-15g, dates-30g, raisin-25g, cashew nut- $5 \mathrm{~g}$, badam $-5 \mathrm{~g}$, sugar- $20 \mathrm{~g}$ )

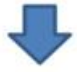

The required quantity of ingredients was mixed with the help of sugar syrup and ghee.

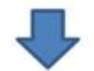

The mixed ingredients were made into a small ball , manually in a quantity for $25 \mathrm{~g}$ each.

Fig 2: Preparation of ODF incorporated laddu

Selection of good quality ingredients in correct proportion

(ODF powder-15g,sugar-50g,butter-5g,milk-15ml, water- $15 \mathrm{ml}$, vanilla essence-3 drops)

Add sugar, butter, milk, water and sodium bicarbonate to a heavy based pan and heat gently till temperature reaches 115 ㅇ C

Remove from heat. Add the essence and dates

Beat the mixture till it is thick and creamy. Pour into greased tin. Mark into squares. Break when cold.

Fig 3: Preparation of ODF incorporated fudge

Sieve the refined wheat flour $(50 \mathrm{~g})$ and baking powder $(2 \mathrm{~g})$ twice. Cream fat (20g) and sugar (30g) till light and fluffy.

Add flour, baking powder, milk powder, ODF fruit pieces (15g) and mix thoroughly.

Sheet the dough and cut with the cookies cutter.

Place the cookies on a baking tray and baked at $180^{\circ} \mathrm{C}$ for 15 minutes.

Fig 4: Preparation of ODF incorporated Sweet cookies 


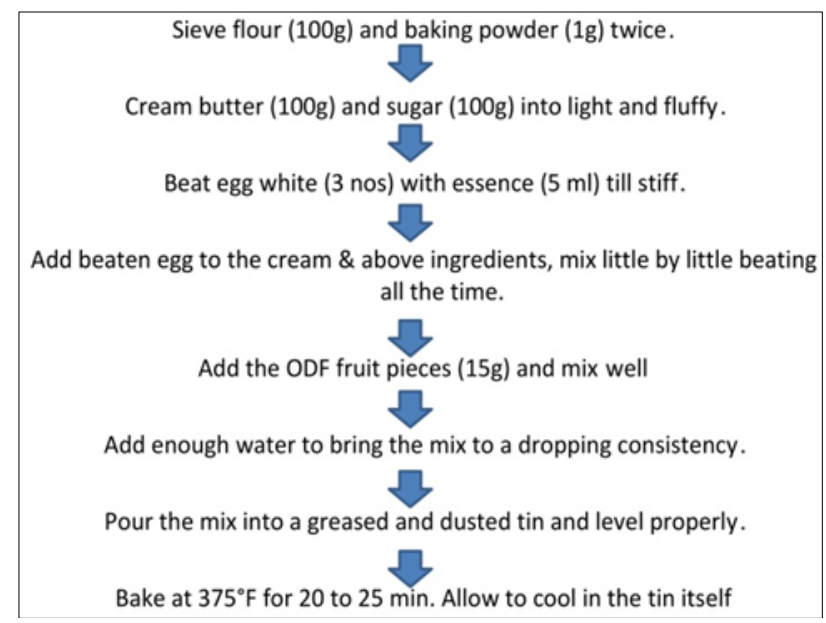

Fig 5: Preparation of ODF incorporated cake

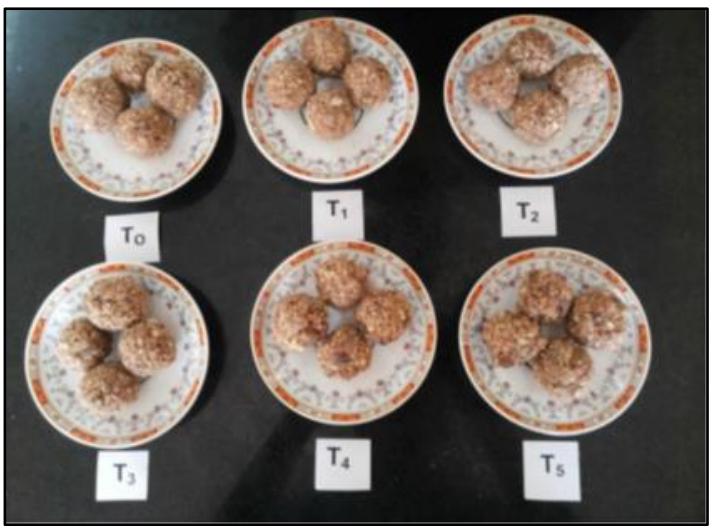

Laddu

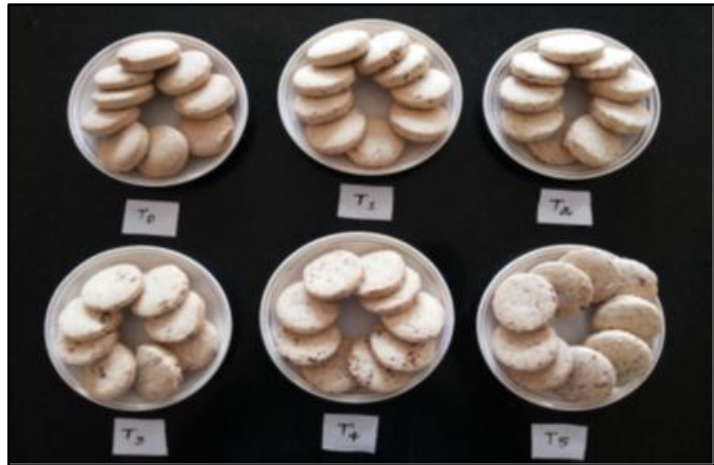

Cookies

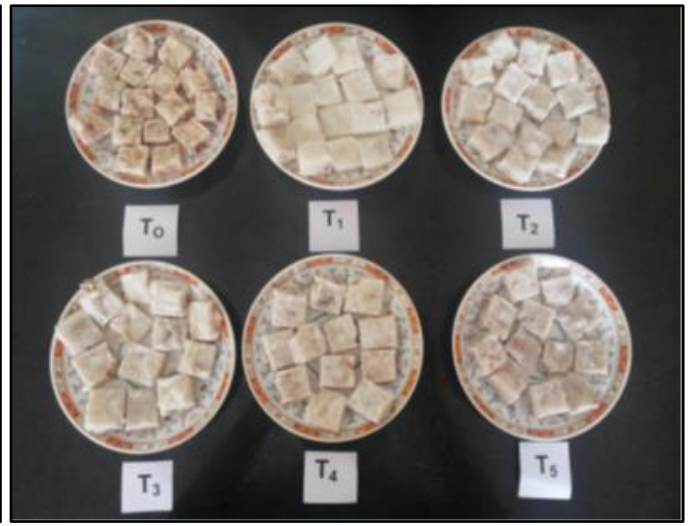

Fudge

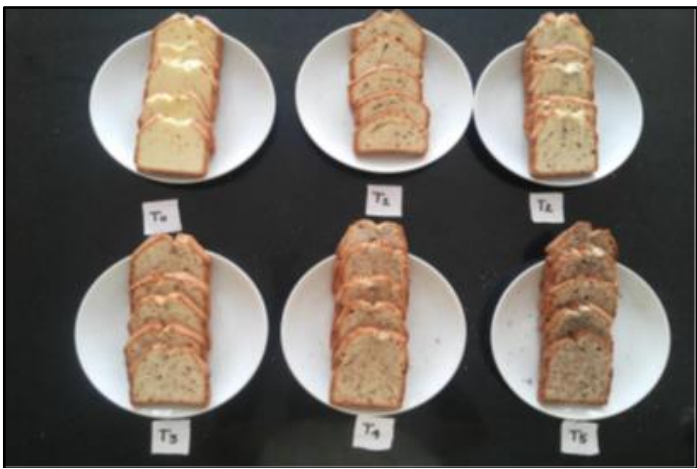

Cake

Fig 6: Osmotically Dehydrated Fig fruit incorporated products

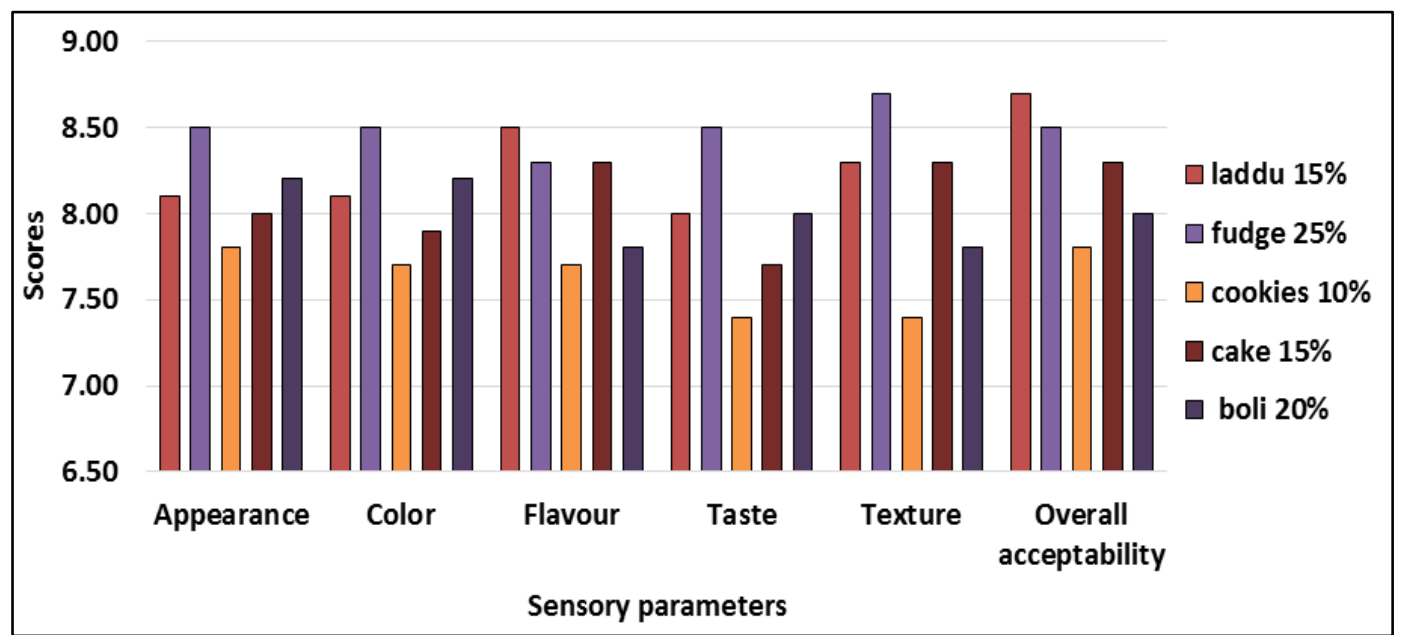

Fig 7: Organoleptic score values for ODF incorporated products 
Table 1: Organoleptic evaluation of osmotic dehydrated fig fruit

\begin{tabular}{|c|c|c|c|c|c|c|}
\hline Treatments & Appearance & Colour & Flavour & Texture & Taste & $\begin{array}{c}\text { Overall } \\
\text { acceptability }\end{array}$ \\
\hline Control & 6.13 & 5.25 & 6.00 & 5.50 & 5.89 & 5.75 \\
\hline $30^{\circ}$ brix & 6.38 & 6.75 & 6.58 & 6.63 & 7.25 & 6.69 \\
\hline $40^{\circ}$ brix & 7.13 & 7.19 & 7.83 & 7.38 & 7.25 & 7.36 \\
\hline $50^{\circ}$ brix & 8.25 & 8.17 & 8.63 & 8.25 & 8.11 & 8.29 \\
\hline
\end{tabular}

Table 2: Nutritional characteristics of osmotic dehydrated fig fruit

\begin{tabular}{|c|c|c|}
\hline Particulars & Fresh fig & Dehydrated fig \\
\hline Moisture (\%) & $79.80 \pm 2.021$ & $9.47 \pm 0.193$ \\
\hline TSS ( ${ }^{\circ}$ brix) & $19 \pm 0.156$ & $80.4 \pm 0.186$ \\
\hline Acidity (\%) & $0.19 \pm 0.001$ & $0.11 \pm 0.001$ \\
\hline $\mathrm{pH}$ & $5.10 \pm 0.100$ & $5.40 \pm 0.029$ \\
\hline Total sugars(g/100g) & $18.04 \pm$ & $76.04 \pm$ \\
\hline Reducing sugars(g/100g) & $8.35 \pm 0.028$ & $4.29 \pm 0.143$ \\
\hline Fibre(g/100g) & $2.05 \pm 0.053$ & $5.94 \pm 0.133$ \\
\hline Ash(g/100g) & $1.57 \pm 0.008$ & $1.93 \pm 0.024$ \\
\hline Vitamin C(mg/100g) & $39.0 \pm 0.928$ & $10.97 \pm 0.149$ \\
\hline Antioxidant(mg/g) & $110.05 \pm 0.907$ & $109.34 \pm 2.455$ \\
\hline Water activity(aw) & $0.94 \pm 0.019$ & $0.744 \pm 0.018$ \\
\hline Colour values L & $70.30 \pm 0.191$ & $75.41 \pm 1.795$ \\
\hline $\mathrm{a}$ & $-4.65 \pm 0.094$ & $-1.50 \pm 0.008$ \\
\hline $\mathrm{b}$ & $12.37 \pm 0.143$ & $15.04 \pm 0.173$ \\
\hline
\end{tabular}

*Values reported are mean \pm SD of three replicates.

\section{Conclusion}

From the study it could be concluded that the fig fruits treated with $50^{\circ}$ brix osmotic solution was found best treatment in terms of drying characteristics and also sensory evaluation and also higher nutritional quality. The developed products such as laddu, fudge, cookies, cake and boli by adding osmotically dehydrated fig were found high overall acceptability during sensory evaluation. Addition of osmotically dehydrated fig fruit in different products provides us a good value addition and scope for the fruit with nutritional value.

\section{References}

1. ASTM. Manual on Sensory Testing Methods (S.T.P.434). American Society for Testing and Materials: Philadelphia. PA, 1968.

2. Bansode VV, Mundhe VP, Zakiruddin M, Khapre AP, Lokhande SM, Pawar VD et al. Processing of Fig (Ficuscarica) for value addition. Beverage and Food World. 1968; 39(5):43-44.

3. Chavan UD, Naikwadi PM, Chavan JK, Amarowicz R. Studies on dehydration of figs using different sugar syrup treatments. Beverage and Food World. 2010; 37(1):6264.

4. Chenlo F, Moreira R, Ferna ndez-Herrero C, Va squez G. Experimental results and modeling of the osmotic dehydration kinetcs of chestnut with glucose. Journal of Food Engineering. 2006; 74:324-334.

5. Dhingra D, Singh J, Patil RT, Uppal DS. Osmotic dehydration of fruits and vegetables: a review. Journal of Food Science Technology. 2008; 45:209-217.

6. Hooti SN, Sidhu JS, Al-Saqer JM, Amani A. Chemical composition and quality of date syrup as affected by pectinase / cellulose enzyme treatment. Food Chemistry. 2002; 79:215- 220.

7. Lerici CR, Pinnavaia G, Dalla MD, Bartolucci L. Osmotic dehydration of fruit: Influence of osmotic agents on drying behavior and product quality. Journal of Food Sciences. 1985; 50:1217-1226.
8. Paakkomen K, Mattila M. Processing, packaging storage effects on quality of freeze-dried strawberries. Journal of Food Science. 1991; 56(5):1388-1392.

9. Ranganna S. Manual of analysis of fruits and vegetables products, Tata McGraw Hill Publishing Co., Ltd., New Delhi. p. 1-2, 7-11 and 13, 1995.

10. Sharma HR, Poojai S, Verma R. Organoleptic and chemical evaluation of osmotically processed apricot wholes and halves. Journal of Natural Product Radiance. 2006; 5(5):350-356.

11. Wang Z, Cui Y, Vainstein A, Chen S, Ma H. Regulation of Fig (Ficus carica L. Fruit colour: metabolism and transcription analyses of the Flavonoid Biosynthetic pathway. Frontier in Plant Sciences. 2017; 8:1990. Doi. 10.3389/fpls.2017. 01900. 